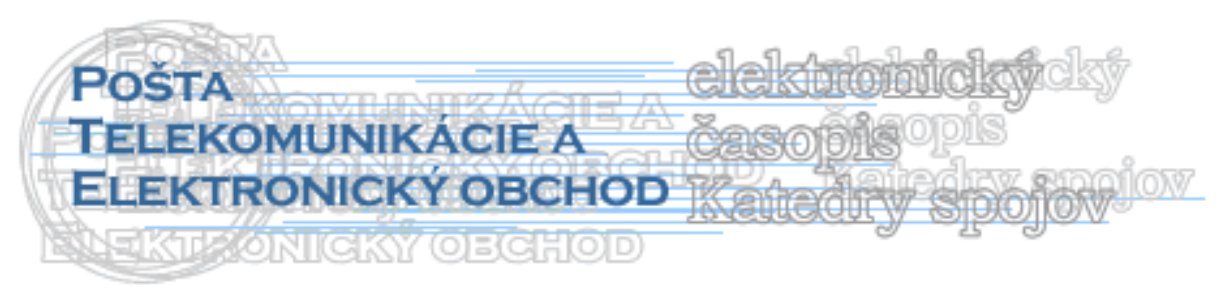

\title{
NEGOTIATING IN THE COVID-19 PANDEMIC
}

\author{
Jana Majchráková ${ }^{1}$, Iveta Kremeňová ${ }^{2}$
}

\begin{abstract}
In terms of the Corona crisis, one of the key areas of strategic procurement negotiating - have changed significantly. For the past few months, almost all negotiations have been occurring virtually. But it seems likely that even after the end of the pandemic, the entire work environment for purchasing managers will become even more "virtual". The article provides an overview of recommendations for virtual negotiations in regard to technical set-up, behavior guidance as well as opportunities \& risks of multiple communication channels.
\end{abstract}

Keywords: digitalization, negotiating, virtual environment.

Abstrakt: $\mathrm{Z}$ dôvodu Corona krízy dochádza $\mathrm{k}$ zmene jednej $\mathrm{z}$ kl'účových oblastí strategického nákupu - vyjednávania. Za posledných pár mesiacov boli takmer všetky vyjednávania vykonávané virtuálnou formou. Je však vel'mi pravdepodobné, že aj po skončení pandémie sa celé pracovné prostredie pre nákupných manažérov stane ešte „,virtuálnejším“. Článok ponúka prehl'ad odporúčaní pre online vyjednávania so zretel'om na technické nastavenia, spôsob správania ako aj príležitosti a riziká viacerých komunikačných kanálov.

Kl’účové slová: digitalizácia, vyjednávanie, virtuálne prostredie.

\section{Negotiating - one of the core tasks of each strategic procurement}

Negotiation can be simply defined as a process of discussing something with someone in order to reach an agreement [1] and belongs to the key tasks of each procurement department, Picture 1. The main area of purchasing includes beside of negotiating also the areas like supplier search and nomination on one hand, also the areas of supplier development in terms of quality and technology and supplier management on the other hand. Within company organizational structure can procurement be defined as follows, Picture 2. The aim of a common company purchasing department includes ensuring efficient production and production control [2]. Both elements can benefit greatly from digitalization. Therefore, it should not be seen as risk but as an opportunity factor.

\footnotetext{
${ }^{1}$ Ing. Jana Majchráková, externá doktorandka na Katedre spojov, FPEDAS, Žilinská univezita v Žiline, e-mail: jana.majchrakova@siemens.com

2 doc. Ing. Iveta Kremeňová, PhD., Katedra spojov, FPEDAS, Žilinská univerzita v Žiline,

e-mail: iveta.kremenova@fpedas.uniza.sk
} 


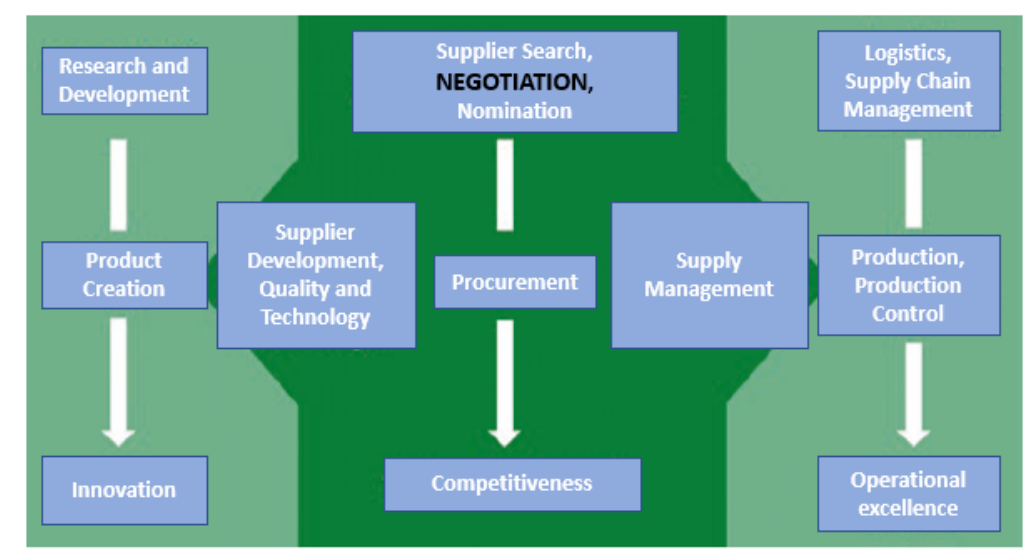

Picture 1: Design area of procurement (Source: Digitalisierung im Einkauf [2])

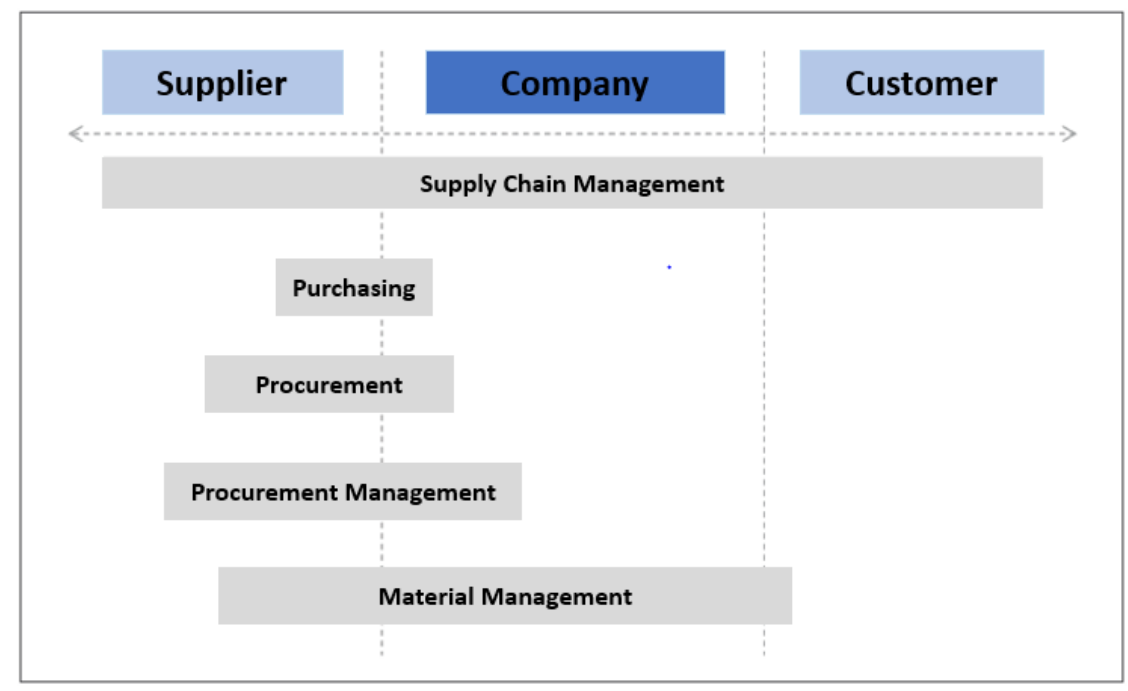

Picture 2: Definition of terms along the value chain (Source: BME e.V. [3])

\section{Virtual negotiations as reaction to COVID-19 crisis in procurement environment}

The COVID-19 pandemic had caused multiple significant changes in companies' structures and behaviors. According BME (Bundesverband Materialwirtschaft, Einkauf und Logistik) study, conducted in March 2020, 27\% of participated companies score effects of the crisis as "noticeable" and $23 \%$ as "strong to critical". And in terms of future plans and actions, because they are not predictable and business is facing a completely new challenge, from this point of the time companies expect more "react and not act" managing [3]. The same trend confirms study conducted by BME in April 2020, which shows that the challenges for industrial buyers, logisticians and supply chain managers are very high in terms of actual crisis. Supply chains of 53 percent of the buyers surveyed by the BME, have been tangibly or critically affected by the crisis. And it is still not over, now we are experiencing the second wave of pandemic increase [3].

One of the most implemented measures during pandemic, the contact restrictions, impacted one of the main tasks of all purchasing managers, negotiating. From this reason it is necessary to look for a completely new way of conducting this task. Modern communication tools, such as Zoom or Microsoft Teams, can be the answer and solution, if companies take some success factors into account. 


\section{Special features of virtual negotiations}

For a conducting of virtual negotiations as well as online meetings in general, specific competencies are required that go beyond pure negotiation in face-to-face meetings. Negotiating virtually tends to leave parties with poorer objective results and feeling less warmth and trust toward one another. Moreover, a meta-analysis conducted already in 2002, suggests that group decision-making is less effective, less satisfying, and more protracted when groups don't communicate face-to-face [4].

Therefore, in case of virtual negotiations multiple elements should be considered in order to ensure a success and expected results:

- trust building might be difficult,

- concentration span may be shortened,

- technical hurdles.

\section{Trust building}

Small talk or creative exchange loosen up the atmosphere and are nowadays a common part of each face-to-face meeting and negotiation. In online (virtual) meetings is usage of this informal communication limited. As a result, it is difficult to establish an emotional bond and trust between the participants which makes further communication and negotiation harder. An experiment done in area of conflict management confirms that starting a negotiation with humor led to better economic outcomes and better feelings between parties. Particularly in the stressful world of quarantines, making a personal connection can have a powerful effect on what follows [4].

\section{Concentration span}

Virtual communication can be perceived as intense. The result is a flattening concentration curve, which can be problematic, especially in long negotiations.

Technical hurdles

Missing or defective technical equipment makes a virtual negotiation very difficult. The technical inadequacies increase the stress factor of virtual negotiations and hinder the trust building [3].

\section{Technical and interpersonal pre-conditions of a successful virtual negotiation}

The mentioned particularities indicate that virtual negotiations require special competencies as well as a proper preparation. In order to achieve the desired success, both technical and interpersonal aspects must be taken into account.

\section{Technical setup}

Mastery of hardware and software, as well as an optimal setting are on place in order to fulfill pre-conditions of a successful virtual communication. Targeted and meaningful usage of technical elements (like camera, chat function, screensharing, ...) support the interaction of the participants and allow the initiator accordingly to control and influence the virtual meeting. Proper illumination, suitable background, camera and microphone setup belong to important factors as well. 


\section{Interviewing}

For an elimination of stress level at the beginning of a virtual negotiation and support personal relationship a small-talk (like by face-to-face meeting) or small compliments related to existing business relationship are recommended.

In order to achieve the desired success in virtual negotiations, preparation has to be done just as intensively as by face-to-face negotiations, Picture 3. Proper preparation and strong negotiation strategy raise not only the chance of successful negotiation result but also allow reduction of negotiation time, because a fundamental part of specific topics is clarified prior to the respective meeting. In case of inadequate preparation of involved parties, long negotiation time is to be expected, because all details must be clarified within the meeting directly or it can lead to multiple negotiation rounds. Negotiation goal, further demands, and their priority setting, alternatives and agenda protocol as key elements of each negotiation preparation have to be on place as well, independently from type of negotiation (face-to-face / virtual).
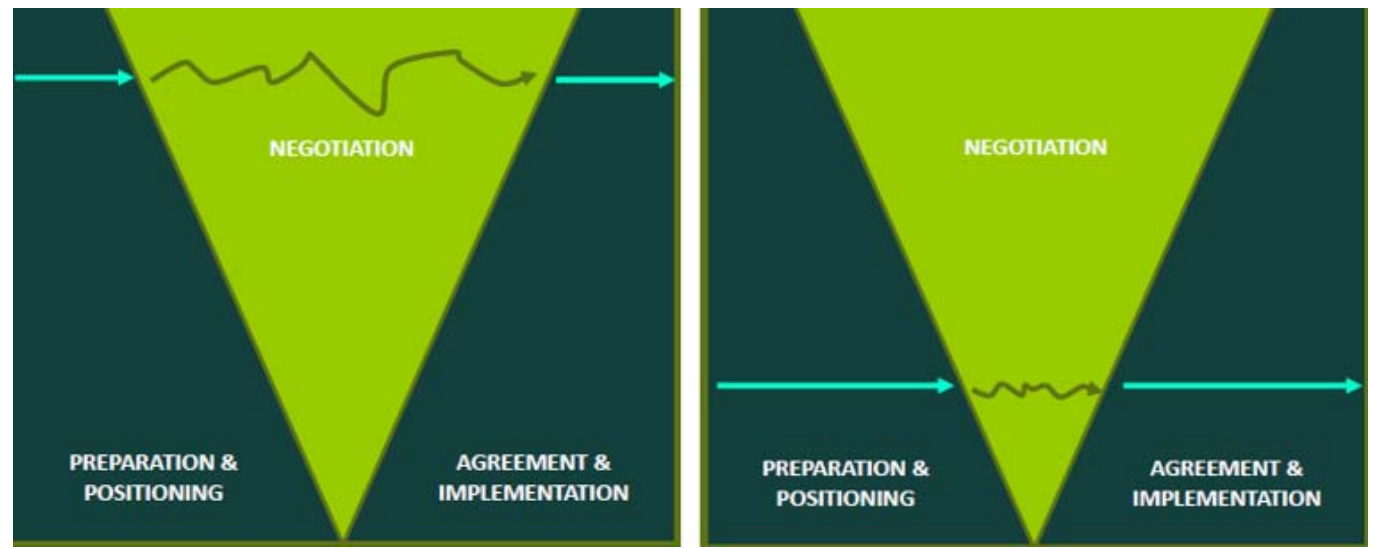

Picture 3: Importantance of a preparation for a virtual negotiation (Source: The GAP Patnetship [9])

Minimalization of a speaking share and maximalization of a visualization help to avoid misunderstandings in online negotiations. Therefore, it is recommended to split screen into at least two parts in order to share for example also agenda or support documentation or pictures.

No Multi-Tasking and eye contact via camera are strongly recommended in online meetings so that the behavior is recognized from all participants as professional [5] [6] .

A research report published by American Psychological Association (APA) confirms that multitasking $\mathrm{f}$. e. on a smart phone while negotiating led to lower payoffs and being rated as less professional and less trustworthy by counterparts [7].

\section{Gender differentiations}

Interestingly, based on a meta-analysis of 43 studies suggests that women are less cooperative in virtual settings than they are when face-to-face, whereas men's tactics don't change as much. It may be that women feel less pressure to be affiliative or polite when they are not face-to-face [4]. Another research confirms that women, in particular, reach better agreement when visual contact is enabled. For men, face-to-face communication can increase discomfort with another male and may be best reserved for difficult and complex negotiations. Furthermore, women tend to do better when they negotiate virtually. It's easier for them to be more assertive, since online or telephone negotiations reduce pressure on women to demonstrate gender appropriate behavior [8]. 
From this point of view, it is highly recommended to consider the gender of negotiation parties as an important element of a proper preparation.

\section{Efficient and effective virtual communication and negotiation}

Each communication channel comes with its own opportunities and risks. Depending on the negotiation strategy, the appropriate communication platform should be selected. Ones the medium was chosen, the maximum of the platform potential should be generated. Following Task-Technology matrixes, Picture 4 and 5, provide a simple overview of efficient and effective communication.

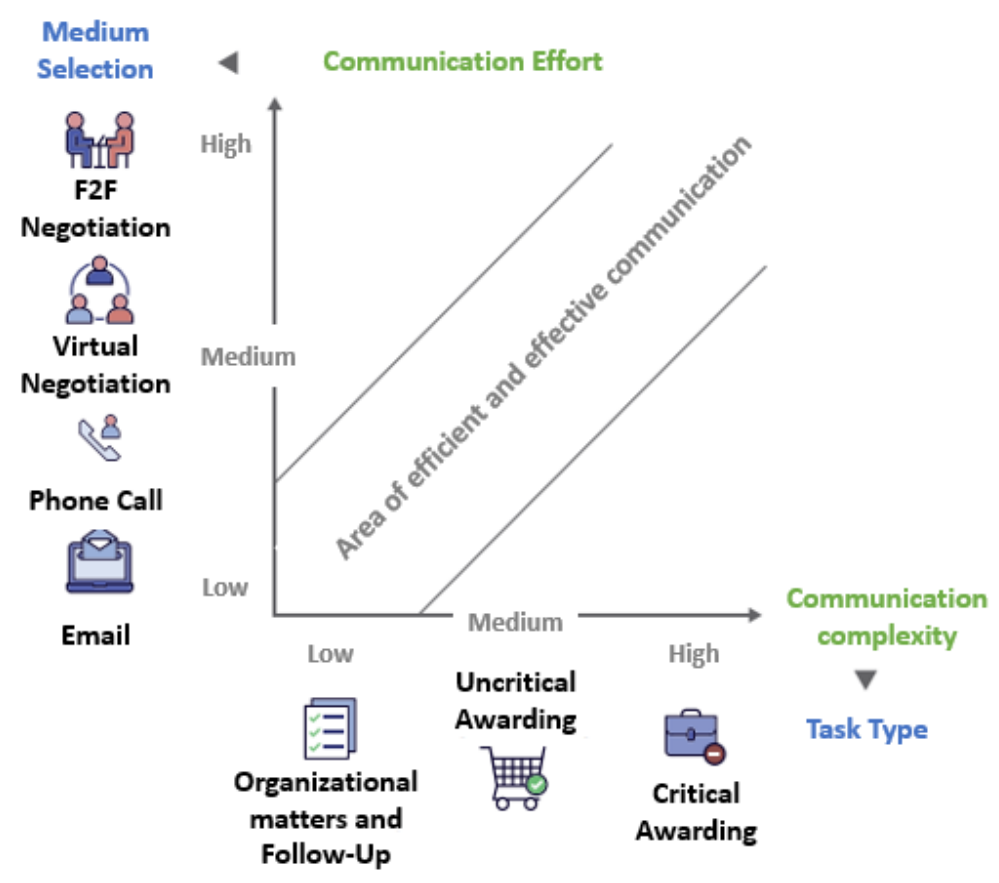

Picture 4: Task-Technology overview (Source: BME e.V. [3])

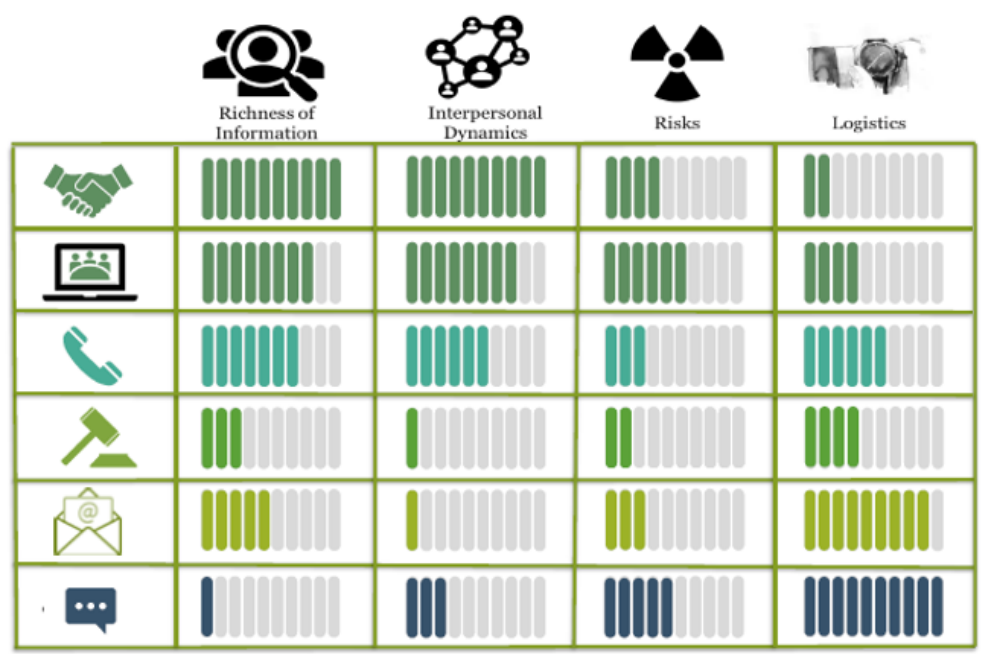

Picture 5: Opportunities \&risks of communication channels (Source: The GAP Patnetship [9]) 
Different media have advantages to help negotiation subtasks relating to time, specificity, and reliability of technical information, efficiency, preconditioning, and other matters. Picture 6 provides an overview of various media and their advantages. It is recommended to switch between platforms to conduct different parts of a negotiation in order to generate maximal benefit of them.

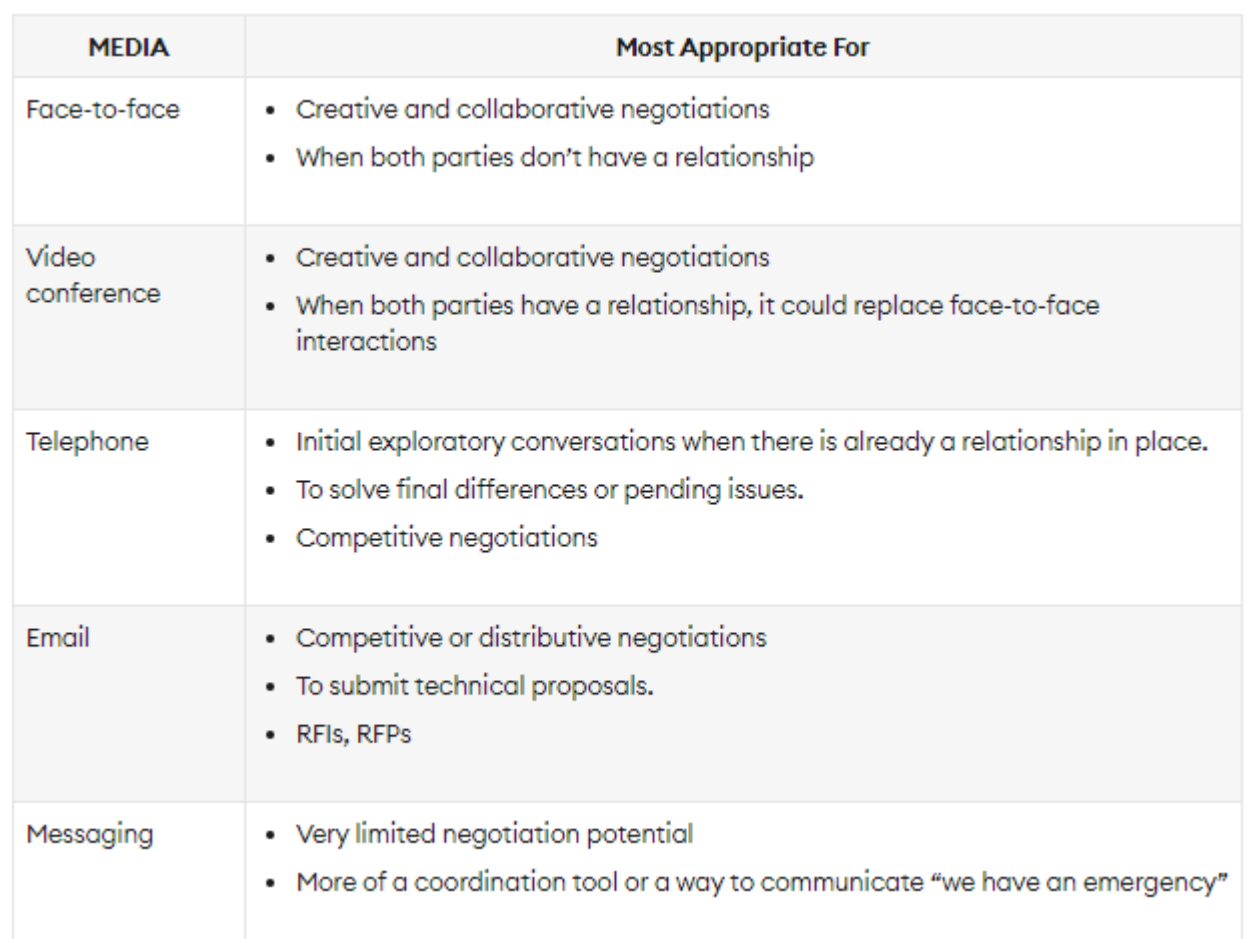

Picture 6: Cross section of various media and their advantages (Source: eLearningindustry [10])

\section{Virtual negotiations have come in order to stay}

The coronavirus pandemic changed the meeting and negotiation "game". The contact restrictions caused by COVID crisis, have accelerated digitization, as a large part of the communication had to be moved to virtual space. The limitations of the crisis have and probably will continue to have an impact globally on the whole Supply Chain Management (SCM). The environment for negotiations has changed over the last months significantly. Face-to-face meetings are not being feasible and given this situation it is necessary to adapt the common approach to negotiations to the best extent possible. Based on selected available researches and practical experiences from specific companies, the article provides an overview on how the environment for negotiations has changed and offers possible ways how to adapt and move to virtual meetings. Recommendations for virtual negotiations in regard to technical set-up, behavior guidance as well as opportunities \& risks of multiple communication channels represents the basic know-how of future purchasing managers. In fact, remote meetings save organizations millions of euros in travel expenses, save managers hours on planes and trains, and help bring environmental costs down. Therefore, it seems likely that even after the end of the pandemic, most of the work environment for purchasing managers will become "virtual".

\section{Sources:}

[1] CAMBRIDGE, [online]. Cambridge Dictionary, 2020. Available on internet: $<$ https://dictionary.cambridge.org/de/worterbuch/englisch/negotiation $>$ 
[2] SCHUPP F., WÖHNER H., Digitalisierung im Einkauf, Springer Gabler, Wiesbaden, Germany, 2018, 171 p., ISBN 978-3-658-16908-4, 2018

[3] BME - Bundesverband Materialwirtschaft, Einkauf und Logistik, 2020, [internal source].

[4] HARVARD BUSINESS REVIEW, [online]. 2020. Available on internet: $<$ https://hbr.org/2020/06/how-to-negotiate-virtually $>$

[5] MORITZ, P, Virtuelle Verhandlungen. In Beschaffung aktuell. ISSN 0341-4507, 2020, č.09, s. 62

[6] LORENZEN D. K., KROKOWSKI W., Einkauf, Springer Gabler, Wiesbaden, Germany, 2018, 234 p., ISBN 978-3-658-07221-6

[7] American Psychological Association (APA), [online]. 2014. Available on internet: $<$ https://psycnet.apa.org/record/2014-13461-007>

[8] FORBES, [online]. 2020. Available on internet: $<$ https://www.forbes.com/sites/jacknasher/2020/05/14/forbes-top-10-to-ace-onlinenegotiations/\#3eef38274545>

[9] THE GAP PARTNERSHIP, 2020, [internal source].

[10] eLearningindustry, [online]. 2020. Available on internet: https://elearningindustry.com/ultimate-guide-types-of-virtual-negotiations

\section{Grant support}

This research has been supported by Ministry of Education, Science, Research and Sport of the Slovak republic and by the University of Zilina. 